\title{
Mycoplasma pneumoniae Measurement
}

National Cancer Institute

\section{Source}

National Cancer Institute. Mycoplasma pneumoniae Measurement. NCI Thesaurus.

Code C156543.

The determination of the amount of the organism assigned to the Mycoplasma

pneumoniae species in a biological sample. 